\title{
VARIABILITY IN MICROHABITATS PREVALENCE IN LOW LYING PEAT POLDER DITCHES OF THE NETHERLANDS
}

\author{
MuKete, B. ${ }^{1}{ }^{*}-$ VERMAAT, J. $^{2}-$ VAN StRAALEN, N. ${ }^{1}$ \\ ${ }^{1}$ Institute for Ecological Sciences, Faculty of Earth and Life Sciences, \\ Vrije Universiteit Amsterdam, \\ De Beolelaan 1081-1085HV,The Netherlands \\ (phone:+31857848990; e-mail: munayesu@yahoo.fr; nmvan.straalen@vu.vl) \\ ${ }^{2}$ Institute for Environmental Sciences, Faculty of Earth and Life Sciences, \\ Vrije Universiteit Amsterdam, \\ De Beolelaan 1081-1087HV,The Netherlands \\ (phone: +31 205989596; e-mail: jan.vermaat@ivm.vu.nl) \\ *Corresponding author \\ e-mail: munayesu@yahoo.fr \\ (Received $26^{\text {th }}$ September 2011; accepted $5^{\text {th }}$ September 2013)
}

\begin{abstract}
Small landscape elements such as ditches are an important remaining refuge for biodiversity in agricultural land especially in the Netherlands. By themselves ditches harbour steep gradients in environmental conditions creating a rich variety in microhabitat availability at the small scale. Regional variation in management and water quality could influence microhabitat variability among these ditches. Some 400 ditches in six major agricultural polder areas around Amsterdam were studied. Data were collected on ditch width, submerged or emergent plants, conductivity, bank height, slope and ditch depth. A principal component analysis using these variables showed observed variability and attributed to the ditch dimensions related to ditch maintenance carried out by the farmers and ditch water quality. Microhabitats prevalence such as percentage algal cover and emergent, vary greatly even in early spring. It was found that, there is a great variability between the ditches within the sampled agricultural polder areas.
\end{abstract}

Keywords: Drainage, ecosystem, management, duckweed, temperature

\section{Introduction}

Recent loss-rates for wetlands worldwide have been among the fastest of any ecosystem type with inevitable impacts on their characteristic species (Keddy, 2000; Balmford et al., 2002). Losses and changes are unlikely to diminish in the future as economic activity, agricultural intensification, global water scarcity and climate-change mineralize remaining wetland areas. The biodiversity of these wetlands has been observed to steadily decline despite conservation efforts and the recognition of their economic value and potential (Wheeler, 1988; Gibbs, 2000; Brander et al., 2006).

In the western part of the Netherlands due to human activities, these wetlands have been transformed into polders since the century, constituted of regular patterned ditches and narrow elongate parcels of lands, with dairy farming as important activity (Van der Linden, 1982; Vermaat et al., 2006). This characteristic landscape pattern that emerged in the presently low-lying peatlands, have been reclaimed to polders since the thirteenth century (Verhoeven, 1992; Vermaat et al., 2006). Ditches are very common elements intersecting the peat polder landscape, adding greater heterogeneity (upto $30 \mathrm{~km} / \mathrm{km}^{2}$ ) of ditch edge to the landscape that generally is under grass with few trees. They form the link between the farmland and larger water bodies such as lakes and canals. Their main 
task is the discharge of excess water from agricultural areas (Twisk et al., 2000; Nol et al., 2008). Similar landscapes can also be found for example, in Germany, West Belgium and England (Blomqvist et al., 2003; Herzon and Helenius, 2008). The general cross-section of these ditches is rather homogeneous (Nol et al., 2008) but it probably depends on the maintenance regime, the aspect of the bank and riparian vegetation (Janse, 1998; Nol et al., 2008). At the ditch scale, this leads to variation in the prevalence of microhabitats. Microhabitats are smaller features distinguishable within a broad scale of qualified habitat elements that form the landscape be it terrestrial or marine (Djomo and Mendy, 2000). Ditches provide habitats with a potential for highly diversified aquatic vegetation and their shallowness offers excellent growing conditions for water plants (hydrophytes). Microhabitats are referred to here as visibly distinguishable structures at the within ditch scale. These structures form important habitat elements for Macroinvertebrate communities, fish, microorganisms and for floating vegetation. Major ditch microhabitats are emergent and submerged plants, steep slopes (embankments), earthen banks, mats of flashy strands of duckweed and floating filamentous algae (Twisk et al., 2003).

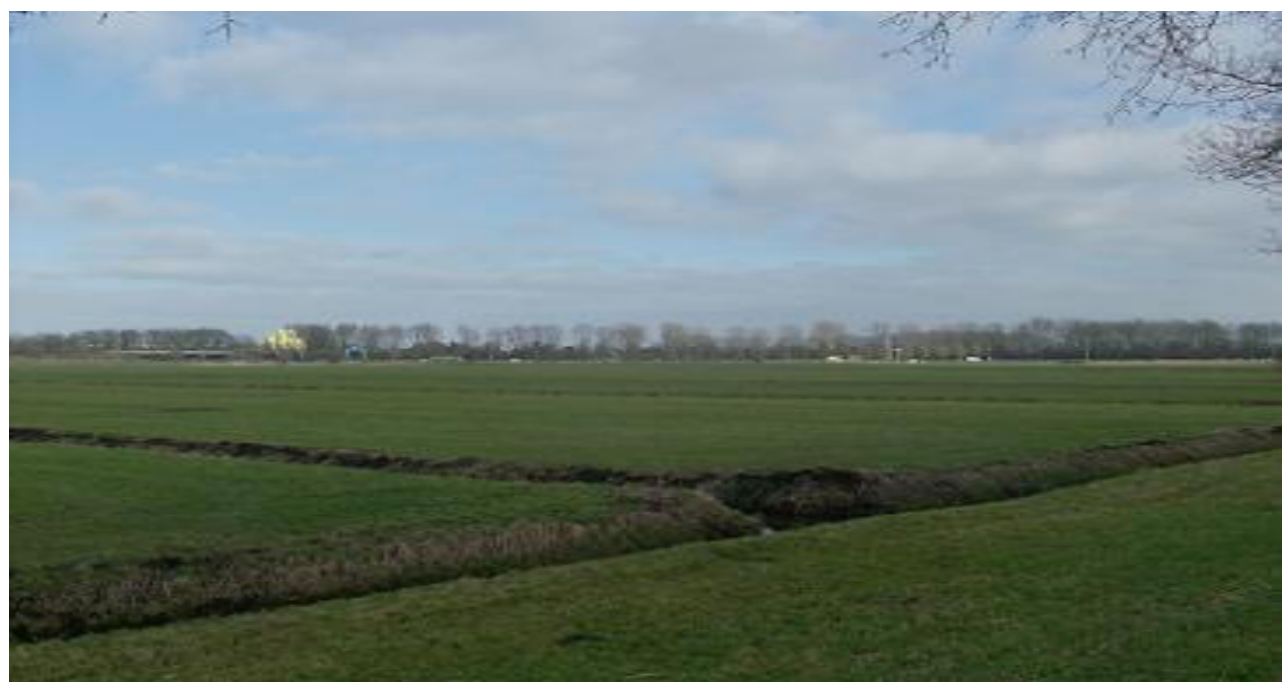

Figure 1. A typical Dutch peat polder landscape, notice the characteristic criss-crossing of ditches in the background

Peat polders are low-lying tracts of land enclosed by embankments known as dikes forming artificial hydrological components that are separated from the surrounding waters by dikes and consequently are drained by pumping. Water from adjacent higher grounds, enters the low-lying peat polder through ground seepage or rainfall and transportation of water by rivers and canals (Janse, 1998). This usually means that the polder has an excess of water that needs to be pumped out or drained especially at low tide. Peat polders are generally subject to a gradually falling land level due to peat mineralization. In the Netherlands, water boards maintain the waterways inside these polders, control the various water levels inside and outside the polders as well as water quality in these ditches (Van der Linden, 1982; Van Strien et al., 1991; Twisk et al., 2000). The water in the ditches in these peat polders is generally eutrophic to hypertrophic, due to mineralization of this peat soil and intensive farming (Berendse 
and Aerts, 1987; Heathwaite, 1990). With an annual ditch management in polder areas, the water boards reduce emergent, submerged and floating vegetation and plants along the ditch bank. Nevertheless, duckweed or floating algae mats dominates these ditches (Twisk et al., 2003). Moreover, the accumulated sludge is removed every 5-7years, fig 6. This is because high nutrient availability causes high plant and algal growth as well as consequent organic sediment accumulation as loose sludge at the ditch bottom.

Peat polders could well exhibit different microhabitat prevalence and variability since they are located in different Waterboard management areas (Janse and van Puijenbroek, 1998). The cumulative impacts of ditch and land management influences ditch depth, ditch water table, ditch bank slope especially through machinery used in ditch cleaning. Peat polders may also exhibit different microhabitat prevalence and variability because of natural conditions such as soil characteristics, nutrient mineralization (due to peat breakdown) and groundwater level. This study, looks at the among ditch variability in these microhabitats and attempt to link this variability to regional variation in management and water quality within six major peat polders around Amsterdam.

\section{Methodology}

\section{Study Area}

This study was carried out in February, March, April and May 2009 in the peat polder areas around Amsterdam, the Netherlands within a radius of $25 \mathrm{~km}^{2}$ around the Vrije Universiteit (Free University) Amsterdam. This is a peat polder area with narrow fields some up to $3 \mathrm{~km}$ in length and $20 \mathrm{~m}$ to $100 \mathrm{~m}$ wide and separated by ditches of 0.5 to $10 \mathrm{~m}$ wide (Fig. 1 and 5). The ditches have dead ends because most are linked to larger ditches running adjacent the fields.

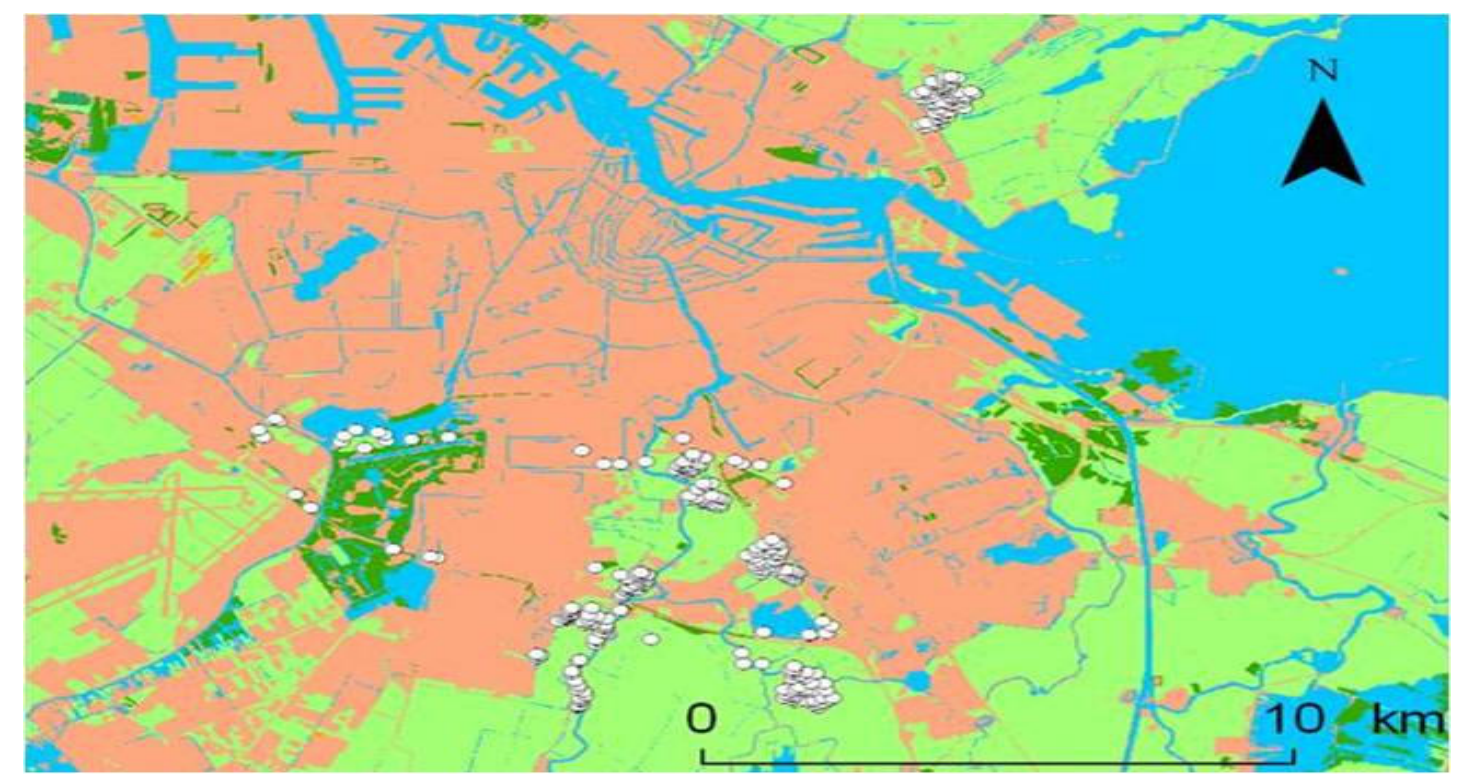

Figure 2. Map showing study area. Notice the variation in ditch distribution among the polder areas of this study. The white circles represent the areas studied whereas the orange colours are human habitats and the green colours are agricultural lands. The blue colours represent water areas 


\section{Study Method}

To understand the variability in microhabitat prevalence in peat polder ditches, a total of 400 ditches in six peat polder areas around Amsterdam were studied. These polder areas were selected as apparently homogeneous with regard to ditch management. Each ditch was studied at least $15 \mathrm{~m}$ from the end or intersecting ditches to sideline similar ditch situations. An overview of the variables studied is given in Table 1 and Fig. 3. The chosen variables are thought to have an impact on the ditch function and also help to describe the physical conditions in and around each ditch alongside adjacent field management.

Table 1. An overview of the ditch variables studied

\begin{tabular}{c|c}
\hline Physical variables & Natural variables \\
\hline Polder area & Algae \\
Ditch width & Duckweed \\
Bank height (ditch water table) & Water Lilies \\
Bank slope & Emerging plants \\
Ditch coordinates & Submerged plants \\
Water depth & Ditch bank trees \\
Sampled area & vegetation) \\
Conductivity & \\
\hline
\end{tabular}

Ditch width (in meters) was estimated with the naked eye after calibration against a meter rule. This meter rule was calibrated in centimeters and marked at length ten centimeters (Fig. 4). It was also used to measure the ditch bank height that is from the water top to approximately the adjacent ditch bank level.

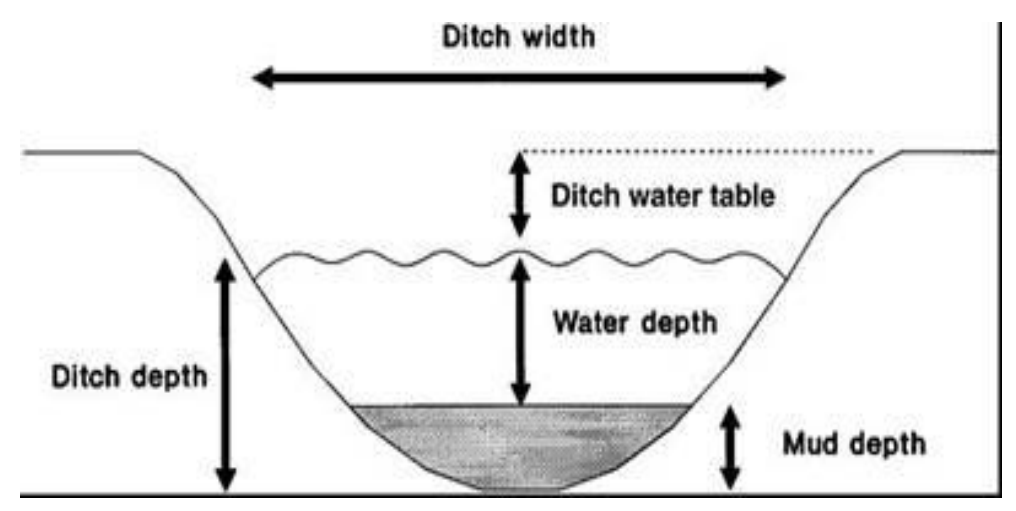

Figure 3. Definitions of the ditch water table, water depth, the ditch width and ditch depth (From Twisk et al., 2000)

The water depth was measured from the water top to the mud level at the ditch bottom. The meter rule was used as a supporting tool alongside a protractor of an unknown model, to measure the angle of elevation or inclination of the ditch bank with $90^{\circ}$ as the highest angle. The conductivity of the ditch water was measured for each ditch and used as an indicator of regional hydrochemistry or ertilizer use. The digital 
conductivity meter used was (model GMH 3410) made by GREISINGER Electronics, Germany. For the sake of consistencies, a constant ditch length of $5 \mathrm{~m}$ was considered for each sampling or as sampling area. A Garmin GPS 12 was used to measure the ditch coordinates (location) in degrees, minutes and seconds. The polder area, the ditch number and the date sampled were recorded for each of the ditches in all the polder areas. Natural ditch variables studied include: total percentage cover of filamentous algae, submerged and emergent plants, duckweed, water lilies and the percentage of trees along the ditch bank. The different plant forms found in the ditch was expressed as a total percentage of both the submerged and emergent plant species with the highest being $100 \%$.

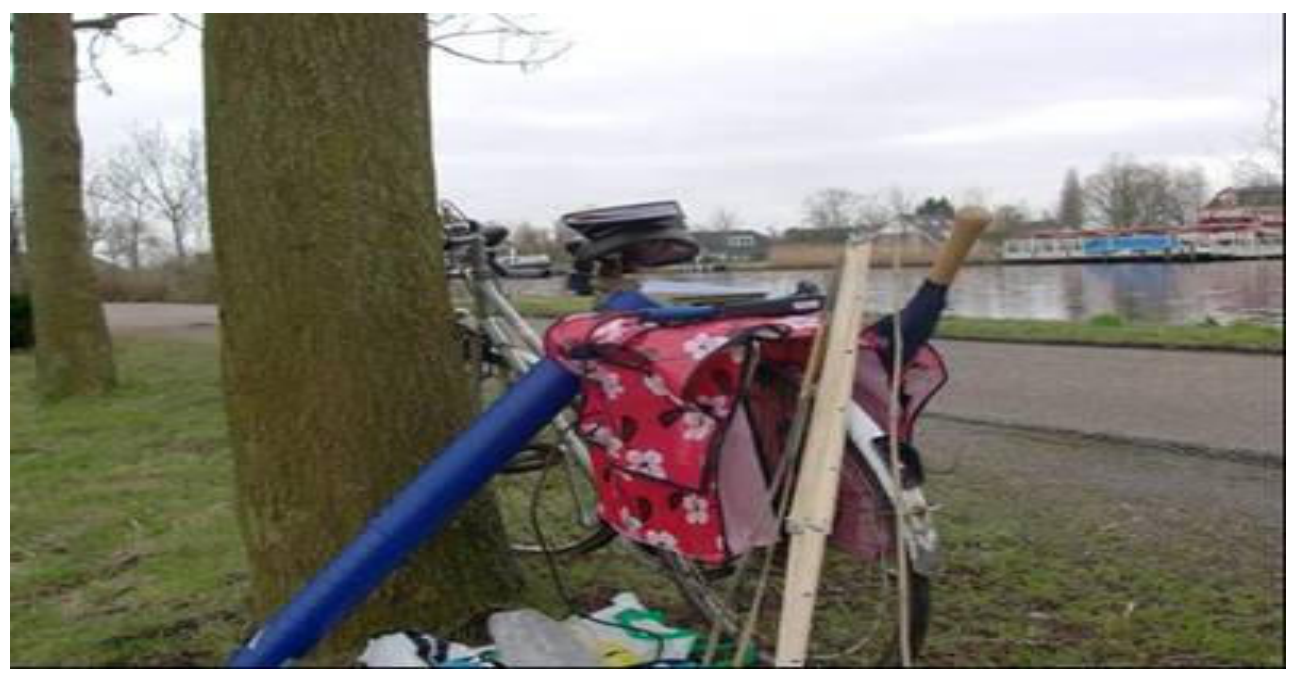

Figure 4. Measuring and study instruments. Notice the bicycle used for movement within the polder areas, the GPS and conductivity meter on the bicycle, an umbrella as well as the calibrated wooden meter rule in the background

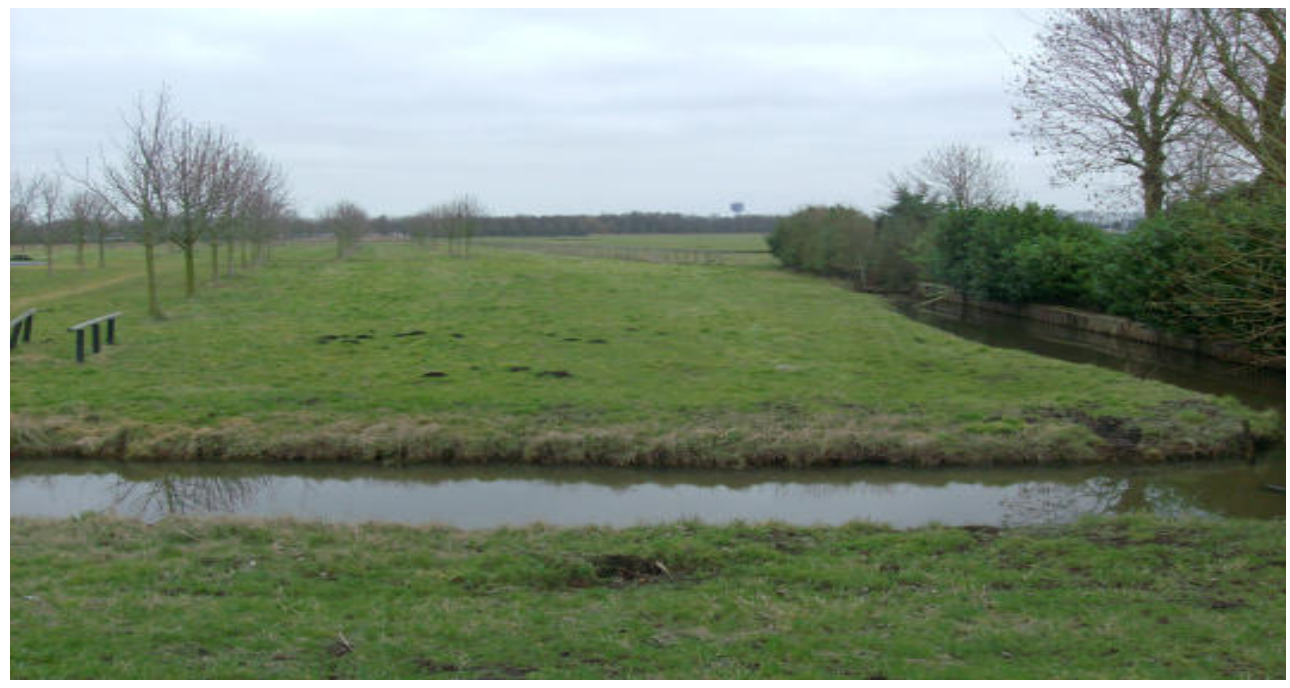

Figure 5. A typical polder ditch in winter, note the absence of ditch bank vegetation and the wide landscape in the background 


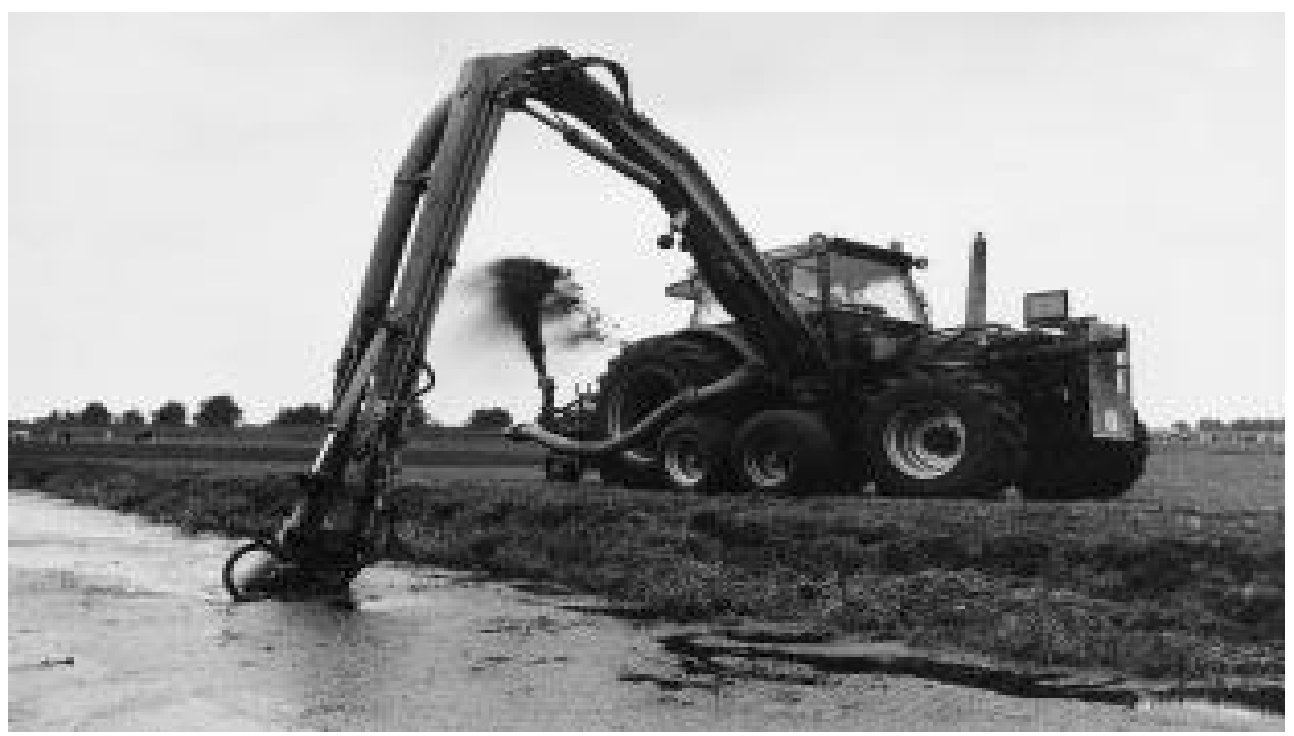

Figure 6. An example of a dredging machine, the suction-pipe. This removes mud from the ditch by hanging a hose in the mud through which the mud is sucked up and sprayed in a wide range over the adjacent field (From Twisk et al., 2000)

\section{Statistical analysis}

A principal component analysis (PCA) was carried out to verify the covariance among variables in the ditches within these major peat polders around. Using One-way ANOVA, the means and standard deviations were calculated per polder with a test for the variance in homogeneity. A Tukey's test was used to test for group means in homogenous subsets among all variables. Linear regression and correlation analysis were carried out to test for independence, linear relations and correlations among the variables.

\section{Results}

One-way ANOVAs among the six polder areas shows variability in ditch parameters (Fig. 7). The mean ditch width was higher in the Badhoevedorp and Ransdorp polders but was smaller in the Ronde Hoep and Abcoude polders (Fig. 7). Microhabitats represented by the visible percentage vegetation significantly exhibited much variability. Filamentous algae were higher in ditches on agricultural lands such as in the Abcoude and Ronde Hoep while ditch depth increased among ditches as we move from purely agricultural lands towards the city such as in Badhoevedorp polder (Fig. 7b). On the other hand, conductivity, ditch width and bank height show no specific trend be it in agricultural or inhabited areas. Emergents were higher in ditches on agricultural lands with little submerged plants whereas the Ransdorp polder for instance had little or no submerged vegetation $(0.5 \%)$. The absence of surrounding trees was most obvious in open agricultural lands especially in Ransdorp with as little as $1.2 \%$ tree cover whereas the Badhoevedorp polder had a $12 \%$ tree cover. 


\section{Covariation among studied variables}
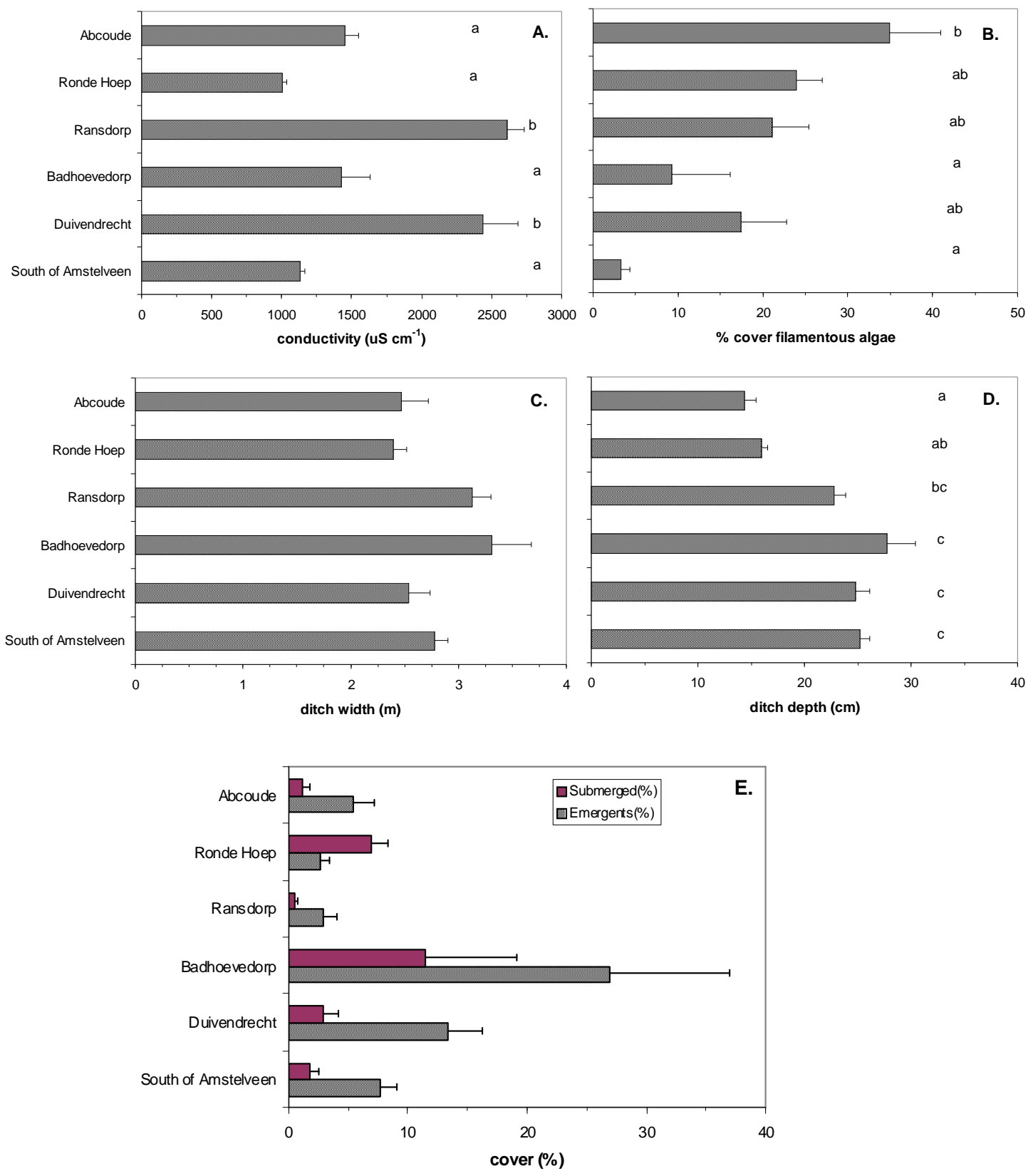

Figure 7. Comparison among six polder areas of ditch dimensions A-Conductivity $(\mu \mathrm{s} / \mathrm{cm}), B-$ Cover by filamentous algae, $C$-Ditch width ( $m$ ), D-Ditch depth (cm), E- cover of emergent and submerged plants (\%)

In a principal component analysis (PCA) (Fig. $8 a$ and $b$ ), the first component explained $20 \%$ of the observed variance and appears to be related to ditch bank height. The second component that explains $17 \%$ of this variance, relates negatively to ditch width and depth within these polder areas. The third and last component that positively 
relates to vegetation represents $15 \%$ of the observed variance (Fig. $8 a, b$ and Table 2). Moreover it is observed that the deeper the ditches, the lesser the algae.

Indeed, bank height and slope correlated positively (Fig. $8 a$ and $9 a$ ). Ditch width and bank height explained only very little of the variation in Percentage algae (Fig. $9 \mathrm{~b}$ and c). Principal component one shows the physical ditch dimensions whereas component two separates ditch width and depth from other bank dimensions such as slope. Moreso, algae vary positively with slope but negatively with depth and with. Other habitat variables such as submerged plants, donot covary with component one or two.

Furthermore when only the correlated variables are considered in a linear relation, bank slope and bank height correlated positively $\left(\mathrm{y}=0.4 \mathrm{x}+42.33, \mathrm{R}^{2}=0.22, \mathrm{P}<0.001\right)$ Fig, $8 a$ and $9 a\left(\mathrm{y}=-3.74 \mathrm{x}+26.82, \mathrm{R}^{2}=0.03\right)$. Ditch width and bank height only explained very little of the variation in percentage algae (Fig. $9 b$ and $c$ ) and they were well separated in the PCA plot (Fig. 8a) especially between percentage algae and ditch width. Still this linear relation reconfirms that, ditch dimensions influence ditch microhabitats.
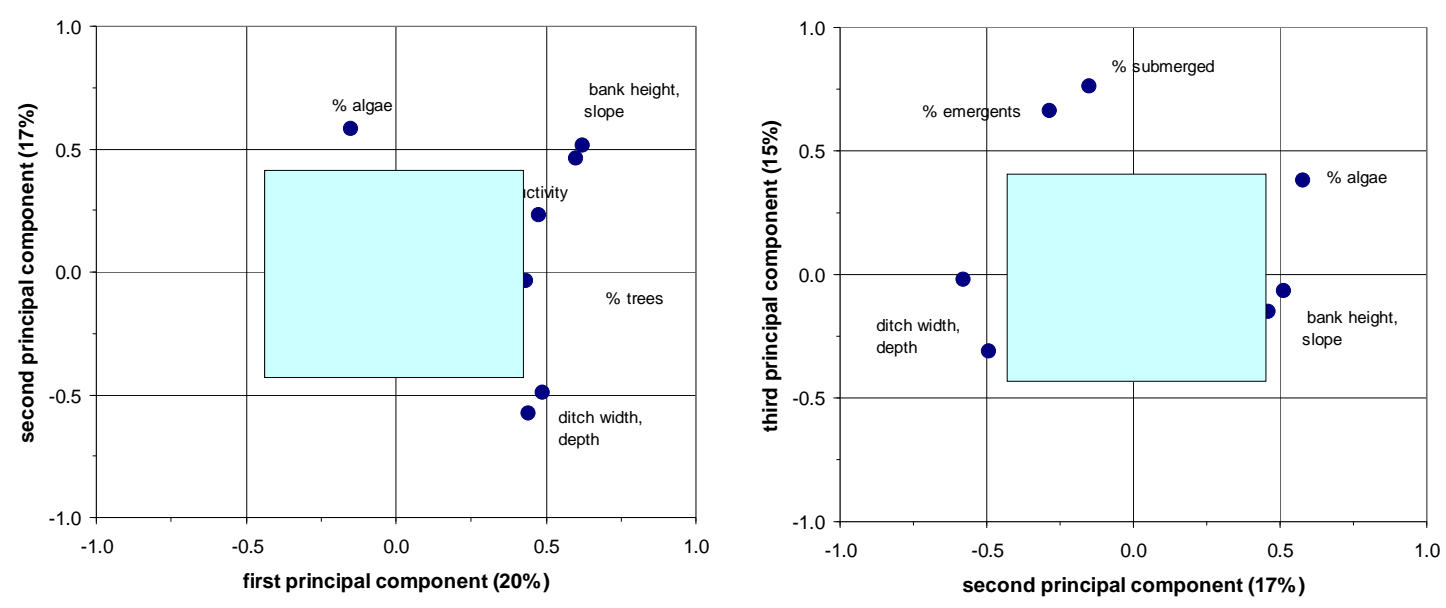

A.

B.

Figure 8. The fig 8 above shows principal component analysis (PCA) of ditch variables. Correlated parameters such as ditch dimensions lie side by side and in the same component

Table 2. Correlation of ditch variables in the six polder areas with a principal component analysis explaining $52 \%$ of the observed variance. Correlations over 0.5 are significant at $P=0.01$

\begin{tabular}{c|c|c|c}
\hline Variable & PC1 (20\%) & PC2 (17\%) & PC3 (15\%) \\
\hline Width $(\mathrm{m})$ & 0.442 & -0.578 & -0.023 \\
Conductivity $(\mu / \mathrm{s} / \mathrm{cm})$ & 0.475 & 0.229 & 0.092 \\
Height $(\mathrm{cm})$ & 0.623 & 0.513 & -0.069 \\
Depth $(\mathrm{cm})$ & 0.488 & -0.492 & -0.314 \\
Slope $\left({ }^{\circ}\right)$ & 0.601 & 0.463 & -0.150 \\
Trees $(\%)$ & 0.435 & -0.037 & 0.151 \\
Emergent $(\%)$ & 0.382 & -0.285 & 0.660 \\
Submerged (\%) & -0.010 & -0.147 & 0.762 \\
Algae $(\%)$ & -0.150 & 0.581 & 0.382 \\
\hline
\end{tabular}


The results of the linear relationships between ditch dimensions are shown below in Fig. 9.

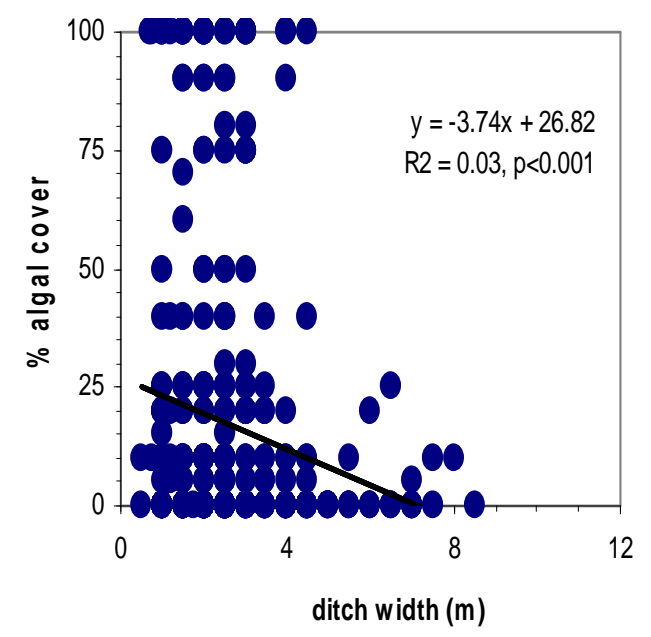

A.

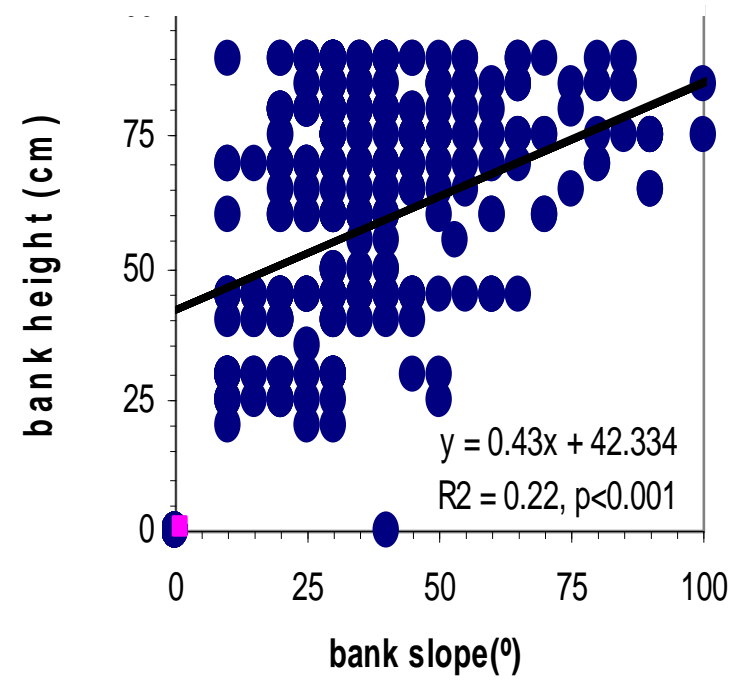

B.

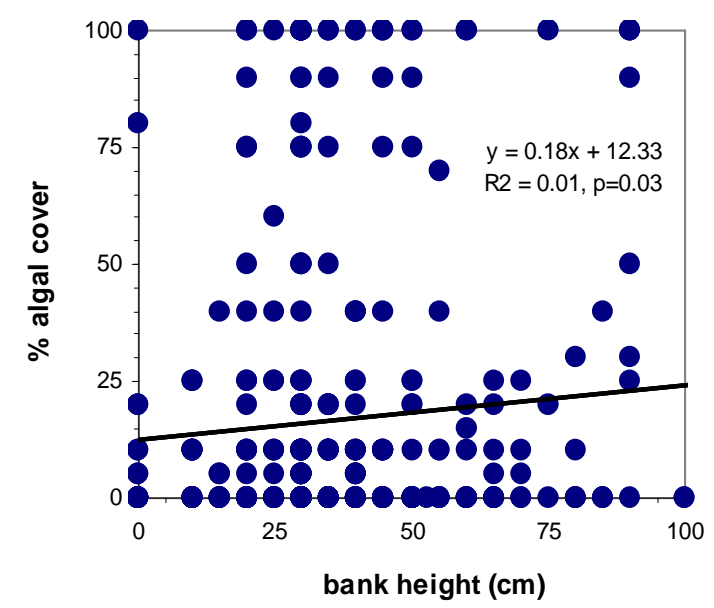

C.

Figure 9. a Percentage algal cover and ditch width, $\boldsymbol{b}$ percentage algal cover and bank height and $\boldsymbol{c}$ bank height and bank slope 
Table 3. ANOVAs of vegetation type abundance versus polder area with ditch morphology and conductivity as covariables. The levels of significance are presented here whereas area is treated here as a random factor

\begin{tabular}{c|c|c|c|c|c|c}
\hline Significances & Area & Width & Length & Trees & Conductivity & Emergents \\
\hline Dependents & & & & & & \\
\% Emergents & $<\mathbf{0 . 0 0 1}$ & $\mathbf{0 . 0 0 3}$ & 0.319 & 0.082 & $\mathbf{0 . 0 0 6}$ & - \\
\% Submerged & $<\mathbf{0 . 0 0 1}$ & 0.926 & 0.757 & 0.165 & 0.919 & $<\mathbf{0 . 0 0 1}$ \\
\% Algae & $<\mathbf{0 . 0 0 1}$ & $\mathbf{0 . 0 0 2}$ & $\mathbf{0 . 0 0 5}$ & 0.541 & 0.416 & 0.287 \\
\hline
\end{tabular}

From Table 3 shows that over and above the major effects of polder area, there are still some observable effects of ditch morphology. For instance, width and conductivity affect emergents whereas emergents covary positively with submerged vegetation. Badhoevedorp polder area has both much higher submerged and emergent vegetation but there is a separate effect. Table 3 also shows that algae respond to width and length thus confirming the results of the principal component analysis (PCA). The highlighted in bold, are the significant levels.

\section{Discussion}

Overall the analyses show great variability in physical appearance of ditches among the six polder areas. Whereas ditch depth and width as well as bank height and slope covaried as pairs, a principal component analysis (PCA) showed that variability in microhabitat prevalence is mostly influenced by ditch dimensions and to a lesser extent by water quality. At the same time, there were similarities in ditch dimensions within the same polder. For instance, the ditches in the Ronde Hoep and Abcoude polder areas have almost the same width and depth as well as those in Duivendrecht and south Amstelveen. The same Waterboard manages these polder areas so it would probably implement the same management strategy (Van der Linden, 1982). It was noticed that the purely agricultural land ditches of Ronde Hoep and Abcoude had low bank heights and correspondingly less steep slopes. This aids in sunlight reaching the ditch bottom and the banks thereby the development of vegetation that forms an important microhabitat in this setting. The absence of surrounding trees in the agricultural lands especially in Ransdorp as opposed to peri-urban Badhoevedorp polder, maybe due to the former influence of the sea in Ransdorp, moreover in newly developed parts of the city these trees are desired for amenity.

The results of this study show that ditch dimensions such as ditch depth and bank height mostly influence microhabitats (Fig $9 b$ and $c$ ). On the other hand, there was no influence of ditch dimensions or morphology on emergent and submerged vegetation in the ditches that were sampled. Though the submerged and emergents sit together in principal component three, they do not relate to ditch morphology. For instance, there was no relation between emergents and bank height or between conductivity and submerged vegetation. This observation brings out the possible interaction of other factors such as intensity of ditch management or maintenance carried out by the Waterboards, the intensity of dairy farming or onsite farm management carried out by the farmer and maybe ditch water quality. However, it was found that (Fig. 8a and b) water quality (conductivity) had no influence on the emergent and submerged 
vegetation, thus suggesting the cumulative influence of another factor in microhabitat variability. Influences of ditch maintenance and onsite farm management strategies were not quantified therefore the deductions on their influence will be mere speculations and assumptions. Meanwhile several studies have also qualified ditch bank orientation as important in ditch microhabitat diversity. This may be related to the prominence in south facing to north facing ditch banks. This orientation could favour ditch bank vegetation even with emergent plants since the south bank receives more sunlight than the north-facing bank (Van Strien et al., 1989).

From another perspective, onsite farm management such as manuring, fertilising and stopping cattle movement along ditch banks may indirectly affect ditch microhabitats (Van Strien et al., 1989). In cases where this occurs, the manure and fertiliser around the ditch banks can easily be washed into the ditches when trampled on by cattle. Furthermore, ditch management or cleaning methods carried out by farmers leads to more plant debris and mud on the ditch banks that often fall back into the ditches when also trampled on by cattle (Van der Linden, 1982). Moreover mechanised ditch cleaning that has now replaced manual methods uses large machinery such as the mowing basket (Fig. 6) to clean the ditches, remove vegetation, mud and sludge. This does not only remove mud but also submerged and emergent plants even those sprouting near the ditch banks. The frequency of cleaning may also influence microhabitats. For example the less frequently the ditch vegetation is removed, the greater the abundance of vegetation. Time of cleaning is another management strategy that may influence microhabitat variability in these polder ditches. For instance, some farmers may clean their ditches once every year and just before winter in October and November whereas the Waterboards usually carry out ditch mud removal at least once every 2 to 5 years. A negative effect of cleaning time is between mid- September and October because regrowth cannot occur before winter as seen during this study especially in the strictly agricultural polders of Ransdorp, Ronde Hoep and Abcoude. But cleaning in June, July or August may result in the regrowth of the emergent vegetation before winter (Twisk et al., 1997; Van der Linden, 1982). A major difference in ditch dimensions was found between Ransdorp and the other polder areas. It was rather difficult to qualify and find differences in management regimes since this was beyond the capacity and scope of this study.

The type of machinery or cleaning method used may also influence microhabitat variability in polder area ditches. For example, due to the low level of microhabitats in the purely agricultural lands of Ransdorp, Ronde Hoep and Abcoude, management such as cleaning and dredging might have been done in mid-September and October just before the onset of winter that preceded this study. Therefore, the effect of dredging on the submersed and floating species may depend on the number of years since dredging. This implies that, though dredging affects microhabitats, it may not create the necessary colonisation conditions for other rare and invasive species. Ditch mud removal is done without disturbing the emergent vegetation because it grows only along the ditch bank whilst the mud is found mainly in the middle of the ditch. Dredging therefore may have little influence on the emergent vegetation. The influence of dredging on microhabitat variability in September or October could also be related to yearly ditch cleaning increasing the impact of nitrogen and phosphorus supply. 


\section{Influence of water quality on microhabitats}

Ditches are maintained on regular bases either by the farmers themselves or by the Waterboards because they are filled up with mud or polluted due to nutrient leaching from agricultural fields and the mineralisation of peat. This cleaning involves the removal of within ditch and bank vegetation including mud, therefore the adverse effects on ditch water quality maybe avoided. The present study further suggests that, due to a stronger dilution of nutrients in deeper ditches, deeper ditches are somewhat less sensitive to nutrient loading than shallow ones. Therefore deeper ditches are important in increasing and improving water flow thus improving on the emergent vegetation. On the other hand, in very shallow ditches submerged plants may survive a higher nutrient loading, if the advantage of the higher light intensity under water outbalances the disadvantage of the higher nutrient concentrations in the water. Dredging may also influence this ditch system since it increases water depth such as to allow for a higher nutrient load while removing sediment rich in phosphorus thereby accelerating ditch vegetation restoration and increasing microhabitats (Van Liere et al., 2007).

In the purely agricultural polder area ditches of Abcoude and Ronde Hoep, the filamentous algae cover increases with reduced ditch depth. This maybe due to the fact that, microhabitats benefit from lower nutrient levels when the water depth increases though light conditions and water temperature may not be optimum in deep water (Barko et al., 1986). Moreover, these limiting conditions at water depths of 50-70 cm could be due to the early sampling period (February and March) when the ditch vegetation is still developing. Most importantly, the vegetation may not be fully developed at the time of year particularly in deeper ditches that were sampled. On the other hand, this early blooming of algae could be a response to an increase in nutrient loads in shallow ditches that favours algal growth. For instance, a higher water level in peat areas results in less mineralisation thus lesser nutrient loads in the direction of the ditch (Van Strien et al., 1989; Van Liere et al., 2001). These lesser nutrient levels favour the growth of submerged vegetation. Furthermore, ditch dimensions such as width and bank height, Fig. $9 b$ and $c$ influence algal occurrence as observed. Correspondingly, the algae cover was observed to increase as ditch width decreased especially in the polder ditches of Abcoude and Ronde Hoep. This is so because, smaller ditches as compared to wider ones are easily filled-up with organic matter especially after long periods without cleaning. This water may become anoxic leading to loss of aerobic life in the ditch (Veeningen, 1983). These ditches would be dominated by submerged vegetation with lots of filamentous and epiphytic algae since submerged rooted plants are favoured at low nutrient loading because their minimum nutrient content for growth is relatively low. These plants use water and sediment pore water and when the nutrient loading level increases, the competitive power of algae and duckweed increases because of the higher nutrient concentrations in the ditch water and because of competition for light (Gerloff and Krombholz, 1966). This result tallies with the observation of this study where algal blooms were witnessed in the agricultural polders of Abcoude and Ronde Hoep.

Though algal communities in nature will always diversify from the usual filamentous algae to include epiphytic species as well, this increase in nutrient loading leaves a surplus of dissolved nutrients in the water column favouring duckweed growth. At high nutrient availability, duckweed grows fast outcompeting submerged plants and algae especially in late summer because of light interception (Portielje and Roijackers, 1995). 
Duckweed was not observed during this study, though its cover may decrease with increasing water depth (Janse and van Puijenbroek, 1998). Although duckweed cover depends on nitrogen and phosphorus concentrations in the water or the nitrogen fertilising level on the adjacent fields, these are often obscured by other factors such as basic oxygen demand, conductivity and pH (De Groot et al., 1987; Philips et al., 1978; Needelman et al., 2007; Boedeltje, et al., 2005). Furthermore, the effect of duckweed biomass on within ditch vegetation will be underemphasised in this study since its appearance is in late spring and throughout the summer months not during the early spring months of this study. This study was done during winter and early spring months (February through March), when there is little or no plant life in the ditches.

Low water quality (eutrophication) was observed during this study within the ditch scale in the polders of Ransdorp and Duivendrecht because fertiliser had just been applied to the fields. This fertiliser may have drained into the surrounding ditches as it rained or as the snow melted. Moreover, during strewing some of the fertiliser may have been strewed into the ditches by the farmer (Fig 7a). Due to this high nutrient levels, ditch microhabitats maybe dominated by a surface layer of pleustophytic plants such as duckweed (Lemnaceae) or floating fern (Azolla), with a disappearance in submerged plants (Portielje and Roijackers, 1995; Boedeltje, et al., 2005). From another perspective, the water balance of the polder ditches may vary because of seasonal changes due to maybe a high evapotranspiration in summer and ground water flow in winter. Since the water chemistry of discharged groundwater such as the presence of $\mathrm{Ca}^{2+}$ water received from eutrophicated rivers or the influence of the sea such as a high salinity and precipitation (low concentrations) differs widely, surface water chemistry would probably depend strongly on the hydrological setting. Though the variation in the hydrological set-up may cause vegetation variability, it would be more evident in summer when most aquatic plants grow (Barengdregt, 1993). Furthermore, chloride and phosphate in the drain or ditch water probably originates from the use of fertiliser and manure and the subsequent mobilisation and infiltration by net precipitation surplus. Therefore, as a result of a high fertiliser use, the ditch vegetation may become very dense causing pollution and further eutrophication. This may be influenced by soil type, ditch water table and by peat since it mineralises when drained and the nutrients may end up in the ditch (Twisk et al., 2000).

\section{Conclusion}

There exists a great variability in microhabitat prevalence in peat polder ditches around Amsterdam. For instance the ditch width varied from mean $0.5 \mathrm{~m}$ in south Amstelveen to $3.3 \mathrm{~m}$ in Badhoevedorp. This variation was noticed for all the ditch variables including the ditch depth, emergents and ditch water conductivity. This variability is attributed to the ditch dimensions probably related to ditch maintenance carried out by the farmers or Waterboards and ditch water quality. Secondly, microhabitat prevalence such as percentage algal cover and emergent, vary greatly even in early spring. This variability is to a limited extent governed by physical dimensions (morphology) of the studied ditches (PCA axis-1 and axis-2) and water quality as reflected in the conductivity. This variability by deduction maybe attributed to farmland management especially with respect to the type of ditch cleaning machine used, method of cleaning and the time of cleaning and as suggested by the difference between for instance Ransdorp polder area dimensions and those of Badhoevedorp polder area. 
Finally though water quality may influence microhabitats variability, this study suggests that the ditch management strategy prevails as causal factor.

\section{REFERENCES}

[1] Balmford, A., Bruner, A., Copper, P., Costanza, R., Farber, S., Green, R., Jenkins, M., Jefferiss, P., Jessamy, V., Madden, J., Munro, K., Myers, N., Naeem, S., Paavola, J., Rayment, M., Rosendo, S., Roughgarden, J., Trumper, K., Kerry-Tuner, R. (2002): Economic reasons for conserving wild nature. - Science 297: 950-953.

[2] Barendregt, A. (1993): Hydro-ecological processes in a polder landscape in the Hydrology of the Dutch polder landscape. - Faculty of Geographical Sciences, University of Utrecht, 153-162.

[3] Barko, J., Adams, M., Clesceri, N. (1986): Environmental factors and their consideration in the management of submersed aquatic vegetation: A review. - Journal of Aquatic Plant Management 24: 1-10.

[4] Berendse, F., Aerts, R. (1987): Nitrogen-use-efficiency: a biologically meaningful definition? - Functional Ecology 1: 293-296.

[5] Blomqvist, M., Vos, P., Klinkhamer, L., ter Keurs, W. (2003): Declining plant species richness of grassland ditch banks, a problem of colonization or extinction? - Biological Conservation 109(3): 391-406.

[6] Boedeltje, G., Alfons, S., Lamers, P., Roelofs, J. (2005): Interactions between sediment propagule banks and sediment nutrient fluxes explain floating plant dominance in stagnant shallow waters Arch. - Hydrobiol. 162(3): 349-362.

[7] Brander, L., Vermaat, J., Florax, R. (2006): The empirics of wetland valuation, a metaanalysis. - Environmental resources economics 33: 223-250.

[8] Brönmark, C., Hansson, L. (2002): Environmental issues in lakes and ponds: current state and perspectives. - Environmental Conservation 29: 209-306.

[9] De Groot, W., De Jong, F., Van den Berg, E., (1987): Population dynamics of duckweed cover in polder ditches. - Arch. Hydrobiologia 109(4): 601-618.

[10] Gerloff, C., Krombholz, P. (1966): Tissue analysis as a measure of nutrient availability for the growth of angiosperm aquatic plants. - Limnology and Oceanography 11: 529537.

[11] Gibbs, J. (2000): Wetland loss and biodiversity conservation. - Conservation Biology 14: 314-317.

[12] Heathwaite, L. (1990): The effect of drainage on nutrient release from fen peat and its implication for water quality, a laboratory simulation. - Water, Air and Soil Pollution 49: 159-173.

[13] Herzon, I., Helenius, J. (2008): Agricultural drainage ditches, their biological importance and functioning. - Biological Conservation 141: 1171-1183.

[14] Janse, J. (1998): A model of ditch vegetation in relation to eutrophication. - Water Science and Technology 37(3): 139-149.

[15] Janse, J., Van Puijenbroek, P. (1998): Effects of eutrophication in drainage ditches. Environmental Pollution 102 Issue 1, Supplement 1.

[16] Keddy, P. (2000): Wetland ecology: Principles and Conservation. The American Society of Limnology and Oceanography book review. - Limnology and Oceanography 46(6): 1581.

[17] Mendy, E., Djomo, J. (2000): Ecologie limitant la croissance et le développement des êtres vivants, cas de l'écologie végétale. - Département de Biologie Animale, Université de Dschang, Cameroun.

[18] Needelman, B., Kleinman, P., Strock, S., Allen, L. (2007): Improved management of agricultural drainage ditches for water quality protection: An overview. - Journal of Soil and Water Conservation 62(4): 171-178. 
[19] Nol, L., Peter, H., Gerard, B., Heuvelink, M., Karin, M. (2008): Effect of Land Cover Data on Nitrous Oxide Inventory in Fen Meadows. - J. Environ. Qual. 37: 1209-1219.

[20] Philips, G., Eminson, D., Moss, B. (1978): A mechanism to account for macrophyte decline in progressively eutrophicated freshwaters. - Aquatic Botany 4: 103-126.

[21] Portielje, R., Roijackers, M. (1995): Primary succession of aquatic macrophytes in experimental ditches in relation to nutrient inputs. - Aquatic Botany 50: 127-140.

[22] Sand-Jensen, K., Søndergaard, M. (1981): Phytoplankton and epiphytic development and their shading effect on submerged macrophytes in lakes of different nutrient status. - Int. Rev. Ges. Hydrobiology 66: 529-552.

[23] Twisk, W., Noordervliet, A., ter Keurs, J (2003): The nature value of the ditch vegetation in peat areas in relation to farm management. - Aquatic Ecology 37: 191-209.

[24] Twisk, W., Noordervliet, A., ter Keurs, J. (2000): Effects of ditch management on caddisfly, dragonfly and amphibian larvae in intensively farmed peat areas. - Aquatic Ecology 34: 397-411.

[25] Van der Linden, H. (1982): History of the reclamation of the western Fenlands and the organisations to keep them drained. - Proceedings of the symposium on peat land below sea level, de Bakker, H., van den Berg, W.M. (ed.), $42-73$ ILRI, Wageningen.

[26] Van Liere, L., Janse, J., Arts, G. (2007): Setting critical nutrient values for ditches using the eutrophication model PCDitch. - Aquatic Ecology 41: 443-449.

[27] Van Strien, A., Van den Burg, T., Rip, J., Strucker, R. (1991): Effects of mechanical ditch management on the vegetation of ditch banks in Dutch peat polders. - Journal of applied ecology 28: 501-503.

[28] Van Strien, A., Van der Linden, J., Melman, C., Noordervliet, M. (1989): Factors affecting the vegetation of ditch banks in peat polder areas in the western Netherlands. Journal of Applied Ecology 26: 989-1004.

[29] Veeningen, R. (1983): The dynamics of dissolved oxygen concentration for water, quality monitoring and assessment in polder ditches. - Environmental monitoring and assessment 3: 321-330.

[30] Verhoeven, J. (ed.) (1992): Fens and bogs in The Netherlands, vegetation, history, nutrient dynamics and conservation. - Kluwer, Dordrecht, Geobotany 18.

[31] Vermaat, J., Goosen, H., Omtzigt, N. (2006): Do biodiversity patterns in Dutch wetlands complexes relate to variation in Urbanisation, intensity of agricultural land or fragmentation? - Biodiversity conservation 16: 3585-3595.

[32] Wheeler, B. (1988): Species richness, species rarity and conservation evaluation of richfen vegetation in lowland England and Wales. - Journal of Applied ecology 25: 331-352. 